[Rae, K. (1999). Stand Downs, Suspensions and Exclusions: Potential Impacts of the 1998 Education Amendment (No. 2) Act. New Zealand Annual Review of Education, 8, 27-44]

\section{Stand Downs, Suspensions and Exclusions: Potential Impacts of the 1998 Education Amendment (No. 2)}

\section{Act $^{1}$}

\section{KEN RAE ${ }^{2}$}

He iti tangata, e tipu; he iti toki, e iti tonu iko A little child will grow; a little adze remains a little adze

Abstract: Whakatauki Maori

This paper discusses the provisions of the Education Legislation Amendment Bill 1997 with regard to suspensions and expulsions, the first revisiting of these issues in legislation since 1978. It comments on the new emphasis on greater flexibility with the more ready availability of "stand downs" (the former principal's suspension for a specified period of up to three days). It notes the more definite timelines surrounding "exclusions" (a redefinition of the former board confirmation of a suspension for an unspecified period) and the aim of creating plain language rules in the interests of fairer procedures more readily understood by all parties. The Bill was passed into law in the last week of the 1998 Parliamentary session.

Varying incidences of suspensions and pressures for change from the time of the 1993 report of the Education and Science Committee on children absent from school are described. Policies complementary to the legislative changes to support schools and families are listed. The prospects of the new settlement concerning issues of school discipline and student access to education are discussed in terms of rival paradigms for the appropriate relationships of New Zealand schools to New Zealand families and communities - on the one hand an "Education market" and on the other a "network of schools".

The December 1996 Coalition Agreement of the National-New Zealand First administration gave expression to the view of the Minister of Education, Hon Wyatt Creech, that the time had come for a review of the legislative framework, after years of rapid change to, and expansion of, the body of education law. In his view, this had been increasingly by accretion rather than according to an overall plan - and in a format less than user-friendly. The Agreement affirmed:

An Education Amendment Bill will be introduced to update the Education Act. The rewrite will endeavour to put in place enabling legislation. Adequate resources will be provided for timely drafting of this legislation.

In advance of the rewrite, on which policy work had been proceeding, and because of a four year hiatus in any fine-tuning to the legislation, in November 1997 the Minister introduced a catch-up/catch-all Education Legislation Amendment Bill. Its Explanatory Note commented:

The Bill contains three matters of educational significance (enrolment schemes, curriculum matters, and suspensions and expulsions) and a number of other amendments, some of which are of a technical nature, which are necessary because the current provisions are dated or have proved inadequate in practical situations.

The draft suspensions legislation in the Bill was intended to:

- reduce the complexity of legislation, in particular by the development of user-friendly procedural rules;

- provide alternative responses, and delay recourse to "unspecified suspensions", which would in future be labelled "exclusions";

- increase flexibility in school responses, particularly with increased availability of principal's "stand downs" (previously "suspensions for a specified period" - of up to three days); and with the creation of a board "suspension with conditions";

- achieve greater procedural fairness in accord with principles of natural justice;

- recognise changes in understanding arising from the UNConvention on the Rights of the Child, in particular the right of the child to be heard on important decisions concerning his or her future; and

- leave the grounds for stand downs and suspensions unaltered, because of the availability of case law concerning their interpretation.

In the 1997 Bill the issue of enrolment scheme legislation was being revisited for the second time since a major revision within the 1989 reforms; the matter of suspensions for the first time since 1978. 


\section{Background}

Section 3 of the new Education Act 1989 emphasised a right to choice of school but noted that exceptions to the exercise of this right had to be accommodated:

Except as provided in this Act or the Private Schools Conditional Integration Act 1975 every person who is not a foreign student is entitled to free enrolment and free education at any state school during the period beginning on the person's fifth birthday and ending on the first day of January after the person's nineteenth birthday.

The principal sections elsewhere in the 1989 Act to provide for those exceptions are those dealing with enrolment schemes, which restrict access in the face of threatened overcrowding (formerly sections 11A to $11 \mathrm{KA}$ and12B - now sections $11 \mathrm{~A}$ to $11 \mathrm{Q})$, and those concerned with suspensions and expulsions, in the face of unacceptable behaviour by the student (formerly sections 13 to 18 - now sections 13 to 18AA, incorporating sections 17A to 17D).

The Education Legislation Amendment Bill introduced in late 1997 dealt with both those areas. It was referred to the Education and Science Select Committee of Parliament for the hearing of submissions from interested parties in early 1998. The vast majority of the 177 submissions to the Committee on the Bill dealt however with two clauses clarifying the role of the Education Review Office in conducting regular reviews of educational programmes provided by parents who have received "long term exemption" from the requirement to enrol their children at a registered school.

The focus of attention of the other submissions fell on the enrolment and the suspension provisions, both areas for increasing public, parental and government concern in the New Zealand context of devolved administration of the national network of schools, exercised by means of single-school boards of trustees.

There was general approval of the modifications to suspensions procedures contained in the Bill. Some families reported to the Committee their sense of injustice at the suspensions procedures employed by principals, and by boards representative of the local parents - or of the dominant groups within that parent community. Support agencies such as Community and Youth Law Projects represented that the procedures employed were inconsistent and often unfair, and that Maori students featured disproportionately in the suspension statistics.
The Commissioner for Children, in a submission to the Minister of Education in April, 1997 (O' Reilly, 1997), well before the introduction of the Bill, suggested some school managers were using the procedures of both enrolment and suspension as a means for positioning their school in the education market. He called for an Education Review Tribunal which would give a right of appeal to families on all issues of enrolment and attendance, including those relating to special education need. The paper was made available to the Select Committee. However, the Bill as introduced and as reported back by the Select Committee in June made no provision for such a body.

The Report Back debate was then suspended because of concerns of some Government back benchers about the enrolment scheme component. The legislation was eventually brought back, and enacted as the Education Amendment Act (No. 2) 1998, in the last week of the parliamentary session in December. There had been substantial redrafting and some additions to the enrolment scheme provisions-but little further amendment to the suspensions sections.

\section{The Legislative Framework from 1978}

The 1998 amendment proposes that the principal of a New Zealand state (including integrated) school will be able (section 14) to "stand down" or "suspend" a student "if satisfied on reasonable grounds" (formerly "if in the principal's opinion") that

a) The student's gross misconduct or continual disobedience is a harmful or dangerous example to other students at the school; or

b) Because of the student's behaviour, it is likely that the student, or other students at the school, will be seriously harmed if the student is not suspended.

Although the test of reasonableness is more explicit, the grounds for a suspension are unchanged from well before 1989. Case law has established the nature of the tests that the principal's action must comply with, given the use of the words "gross" and "continual" - and that there is a second limb to the test, that of "harmful or dangerous example". Urgent action continues to be available to a principal in the event of potential serious harm to a student or students.

The case law is limited because usually only those familiar with the courts and prepared to invest significant sums of money (viz., families with lawyer parents) have been prepared to seek a judicial review of a board's action. The great majority of suspensions do not impact on 
families of this type. The case law that exists has, however, established that the principal in exercising a discretionary power, and the board in considering appropriate follow-up to a suspension, must consider each case on its merits and may not act from blanket rules or with a closed mind. (M v Board of Trustees of Palmerston North Boys High School [1997] 2NZLR60).

The latest judgement on suspensions procedures ( $S$ and $D$ and $M v$ Auckland Grammar School Board of Trustees, Auckland High Court M477/97 June 1998) has made clear that both the principal and the board are required to consider all of the options available to them at each stage when considering any case. (In this latest case the judge also awarded substantial costs to the appellants.)

In essence, the principal has the power to suspend a student and the matter is reported (but with the exception noted in the next paragraph) for further decision to the school's governing authority (since 1989 a board of trustees). The board has had the power to lift the suspension, which could be with conditions imposed (the Act now specifies that such conditions be "reasonable"), or to extend the suspension from time to time (or to expel a student over 16).

The suspension procedures were last amended in 1978, when provision was made for a new "suspension for a specified period" - that is for a period of up to three school days. A suspension by the principal of this type was not a matter for subsequent board deliberation, but still had to be reported to the board. It was proposed on its introduction in 1978 as a device to provide a "time out" or cooling off period, for both the student and the school.

The new suspension at that time, however, placed extra procedural requirements on the principal, and on the then Department of Education, which had to have a representative attend a meeting with the principal if one was requested by the parent. In addition the provision was made available for use with any student only once in any school year. The concept of a time for "cooling off" was replaced by the concept of "a shot across the bows", which constituted in effect a final warning

\section{Pressures for Change}

The provisions outlined above reflect earlier times when students who left school early, whether voluntarily or involuntarily, could be expected to find employment readily. Those conditions no longer apply. The provisions also reflect a view that secondary schooling in particular is a privilege and not a right - able to be withdrawn regardless of the major consequences for the future of the young person involved. International conventions and a human rights perspective increasingly question the validity and the acceptability of this perspective.

Partly as a result of steeply rising suspension statistics, and partly out of its concern that, despite the raising of the school leaving age to sixteen years from January 1, 1993, the number of young people out of school seemed to be on the increase, the Education and Science Select Committee of the 1993 Parliament conducted an enquiry into Children at Risk through Truancy and Behavioural Problems.

In its 1995 report the Committee raised the following concerns:

- shortcomings on issues of natural justice with regard to suspensions procedure, in particular such matters as the family's right to know the process that will be followed and the lack of the student's right to be heard;

- the limited rights of parents in practice to contest decisions or to appeal decisions;

- the conflict of roles for the principal, as initiator of the suspension, and as a full member of the board of trustees which later decided on follow up action (even though the principal would usually withdraw);

- the potential length of suspensions for an unspecified period, the rise in suspensions, disproportionate suspension of Maori and Pacific Island boys, and the prevalence of "kiwi suspensions" (illegal procedures intended to have the student leave the school); and

- the need to recognise changed understandings on the rights of young people arising from the United Nations Convention on the Rights of the Child.

The then National government called for a report from the Ministry of Education on the relevant legislation and was advised in 1996 that, in addition to the points well made by the Committee, sections 13-18 of the Education Act 1989:

- were detailed and complex and contained inconsistencies in the method of calculating of periods of time;

- appeared to allow double jeopardy when a student who had resumed schooling after being suspended sought later to enrol at another school 
- and in particular had no timelines:

- for principals to report to the Secretary their inability to have a suspended student enrolled at another school;

- for ending the suspension of a student under 16; or

- for a board to consider the suspension of a student over 16.

The 1997 Bill sought to meet almost all of those points, with the exception of the matter of appeals. If the Government's concern was to improve student retention and student achievement by reducing suspensions, it had available to it at least the following further strategies:

- earlier interventions in support of students and families, which could provide alternative outcomes to suspensions and increase the chances of the student's retention in schooling or alternative educational provision;

- better prescription of process and better availability of that information, to build increased fairness into the process when students are suspended;

- increased support or advocacy available to the student and parents when a suspension is being considered.

Some policies to supplement the legislative changes are noted below.

\section{The New Legislative Provisions}

The suspensions and expulsions provisions of the legislation enacted in December, 1998 contain for the first time a purpose clause (new section 13):

The purpose of the provisions of this Act concerning the standing down, suspension, exclusion, or expulsion of a student from a state school is to -

a) Provide a range of responses for cases of varying degrees of seriousness; and

b) Minimise the disruption to a student's attendance at school and facilitate the return of the student to school when that is appropriate; and

c) Ensure that individual cases are dealt with in accordance with the principles of natural justice.
The Education Act 1989 has accordingly been amended to:

- provide greater flexibility for the principal to suspend for a specified term, i.e., to "stand down" the student for a period or periods of up to 5 school days in one term and for no more than 10 school days in a year;

- $\quad$ provide a new option for the board "to extend a suspension with conditions". The conditions must be reasonable and related to the offence, and aimed at facilitating the return of the student to the school. The principal will retain a responsibility for the educational programme of the student;

- give the Secretary the power to make and publish procedural rules for principals and boards to follow, to ensure a fair hearing for a student "stood down" or "suspended" for any period;

- require the Secretary in making rules to take account of principles of natural justice, and before making any rules to give public notice, invite comment and consult sector groups;

- remove the total bar to a suspended student attending a school so that a principal can require attendance for purposes of guidance and maintaining the student's educational programme, and the parents can on similar grounds request contacts by the student with the school;

- make provision for the right of the student to be heard and to be represented;

- make provision for the use of the term "exclusion" when the board extends a suspension indefinitely, and requires that the student be enrolled at another school;

- introduce a time limit of 10 school days on the responsibility of the principal to try to arrange enrolment in another school for a student excluded by board decision, or inform the Secretary of the need for other action;

- require the consultation by the Secretary on placement of an excluded student in a new school to include consultation with the student; and

- consolidate and modify the provision from the "rump" 1964 Education Act concerning private schools, so that they notify all suspensions and exclusions to the Secretary. 
The flexibility achieved from making the "stand down" more available, and for a period of up to five school days, (section 14(2)) is intended to decrease the likelihood of early recourse to an "exclusion". Another new option will permit a board to "extend a suspension with conditions" (section 15(1) (2) and (2A)). The conditions will need to be reasonable and related to the offence, and intended to secure the return of the student to the school. They could provide for the student to be off site, but preparing for a return to school. The student could be required to take drug counselling, for example, or attend an anger management course.

Section 17A(1) requires a principal to take all reasonable steps to ensure that a student suspended from school has the guidance and counselling that are reasonable and practicable in all the circumstances of the suspension. The principal will have responsibility for ensuring a satisfactory education programme for a student "suspended with conditions". Section 14(2) has as a consequence been amended so that a principal can require attendance for purposes of guidance and maintaining the student's educational programme, and the parents can on similar grounds request contacts by the student with the school. This would allow the student, for instance, to submit assignments for internally assessed national qualifications.

The former "unspecified suspensions" for students under sixteen will no longer be able to be extended without limit. In cases when a board within the required period of seven days resolves to exclude a suspended student, the principal will either arrange enrolment in another school, or in ten school days advise the Secretary (section 15(4) and (5)). The powers of the Secretary of section 16 have been reordered - the Secretary will continue to be able to lift a suspension and require re-enrolment of a student, "if satisfied that it is not inappropriate for the student to return to the school"; or direct the board of another state school that is not an integrated school to enrol the student. This could include The Correspondence School - although a recent comment by the Education Review Office to the Select Committee has called for a revisiting of the policy of making such placements.

The proposed Secretary's rules (new section 18AA) will make provision for:

- the procedural requirements to be followed

- the parties to be consulted
- the notice to be given to the student and appropriate members of the student's family;

- time limits;

- $\quad$ protection of the privacy of individuals; and

- "such other matters as the Secretary considers desirable in the interests of natural justice".

Preliminary development undertaken in early 1998 by the Ministry of Education of an outline for the rules, as it prepared for the consultation required in the new legislation, has established that any procedures fulfilling principles of natural justice will provide at least for the rights of the student and the family to:

- be given notice of the possible outcomes;

- know the reason for the standing down or suspension;

- know the information the decision is based on;

- be able to comment on that information;

- be able to correct adverse or biased material and to challenge irrelevant material;

- have time to prepare a response to the information;

- have standing down/suspension procedures applied with consistency; and

- be represented at a meeting or hearing about the standing down or suspension.

Because of the provision for wide consultation on the procedural rules, (which need to be in user-friendly language accessible to both families and students and to the lay members of boards), the Act has made provision for the rules to come into force on a date to be notified by Order in Council, after the completion of that consultation.

\section{Discussion}

\section{The varying incidence of suspensions}

The number of suspensions increased by nearly 100 percent in the four year period 1992-1996, from a total of 5082 suspensions in 1992 (of which 3487 were for a specified period - i.e., up to three days, after which the student returns to school) to 10,016 in 1996 of which 6545 were for a specified period. The suspension rate was up again in 1997 
to 11,439 (with 7335 or 64 percent again for a specified short term of up to three days). Thus the suspension rate per 1000 students increased from 9.9 in 1993 to 16.8 in 1997 (Minister of Education, 1998, pp. 38-39).

Although Maori constitute 20 percent of school rolls they are disproportionately represented in suspension statistics, comprising 44.1 percent of the suspensions in 1997 for which the student's primary ethnicity was identified. Students aged 14 and 15 are most at risk of being suspended (52\% of the total in 1997) and boys more than girls (74\% of suspensions in 1997). The most common reported behaviour in 1997 was continual disobedience $(21 \%)$ followed by physical assault on other students (21\%). During that time 1841 students $(16 \%)$ were suspended for the misuse of drugs (usually cannabis).

The 1996 School Sector Report of the Minister of Education noted that students in schools in deciles 3-5 were most at risk, constituting 42 percent of all suspensions (Minister of Education, 1997, pp. 33-34). The 1997 report, however, using a revised format a year later in June, 1998, reported an incidence of suspensions per 1000 students greater in "schools drawing on lower and middle socio-economic communities" than in those with students "from higher socio-economic communities" - apparent in both primary and secondary schools.

In 1997, in primary schools drawing on lower-SES catchments there were 4.7 suspensions per 1000 pupils; in schools with middle-SES catchments 3.6 per 1000; and in schools with higher-SES catchments 1 per 1000 . The comparable secondary figures were 61 per $1000,42.6$ per 1000 and 22.4 per 1000 , respectively.

Research by Overton (1995) and by Thrupp (1997) has suggested that while some secondary schools have used indefinite suspension as a routine disciplinary measure for certain types of behaviour (e.g., for possession of cannabis or swearing at teachers) others use the suspension only as a last resort when other disciplinary measures have been tried and have failed. The number of suspensions in any school is thus not a indicator of itself as to the speed (or reluctance) with which a school moves to suspend a student.

Evidence before the Select Committee from an Auckland secondary school outlined its use of a family conference procedure (as in Youth Justice procedures) to seek to arrive at a resolution of the issues disrupting the relationship of the student and the school. It was suggested, however, that the tight timelines could prevent full working through of the issues. A Community Law Project reported to the Committee its success in standing alongside the student and family in suspension hearings and of being able to move the focus of the board's consideration from the establishing of a penalty to the achieving of a management plan for the student's future behaviour and progress at school.

\section{The climate in which schools are operating}

Representations to the Select Committee on behalf of a secondary principals association suggested that in the 1990s there had been a "sea change" relating to the demands that parents and students made on schools.

Parents want and even demand that the learning of their son and daughter should in no way be compromised by the disturbing or disrupting of the class. They are aware, in a way that parents in the seventies seemed not so concerned about, that the schooling of their son/daughter is vitally important to their life chances and they require schools to be much firmer in the handling of disciplinary matters. When this is coupled with the fact that schools are very much in competition with one another, and that the disciplinary climate of a school is one of the major factors by which a school is judged, it is not surprising that the number of students being suspended has risen over recent years.

A paper on an Education Review Tribunal from the late Commissioner for Children, made available to the Select Committee, noted that the increase in suspensions in New Zealand schools paralleled large increases in some Australian states and in the United Kingdom. He rejected the suggestion that it could be linked to the abolition of corporal punishment in 1990 and stated, "A more important influence is likely to be the increasing competitiveness between schools following the 1989 education reforms" (O'Reilly, 1997, p. 15). This would conform to the thesis of Grace, in his address to the 1998 NZEAS conference, that the reforms encouraging the development of an education market represent not just the "commodification of education" but also the "commodification of students".

As presented in the 1996 Ministry report, the number of suspensions from decile 3-5 schools would support the thesis of three "circuits" of schools in the New Zealand education market. This concept from English studies of school choice (Ball, Bowe and Gewirtz, 1995) was applied in New Zealand research (Lauder et al, 1994), and expanded into study of choices by families and students in this country of "local", "adjacent" or "distant" schools. Certainly it provides a frame for the 
evidence to the Select Committee of the representatives of the Auckland co-educational school already referred to.

Their school had a falling roll and was in danger of decline into the lowest circuit (i.e., attended only by local children whose families did not exercise, or were unable to exercise, any choice). They described to the Committee the double bind that they found themselves in. They sought to work for the retention of students, who would have been suspended for similar behaviour in neighbouring "middle circuit" schools or the more distant, usually long established, prestigious and single sex "upper circuit" schools. Because their school was in an area of population decline and had spare capacity and therefore no enrolment scheme, those difficult students were very likely to have been placed with them by the Secretary, after being suspended from one of the other "middle" or "upper" circuit schools (possibly to sustain public perceptions of their "discipline climate").

The school's representatives proposed that their dilemma be resolved by the Secretary developing for every school, including those in the upper circuit, a quota for placements, based on roll number. They also noted that larger, higher-SES schools were more capable of absorbing students with difficulties. Their proposal has however not been taken up.

The new legislation provides increased flexibility of response by principals and boards, with the aim of retaining students in school. Thrupp argues, however, that schools are set within a changing and more competitive society, in which differences have increased between families with regard to their social and economic capital (Thrupp, 1995; 1997). Those differences stem from policies in fields beyond education, particularly the health, welfare and housing reforms dating from the 1991 Budget, and the new stresses generated from that time are impacting differentially on student behaviour and performance at school. They have also impacted differentially on the workloads and focus of leaders and teachers in schools.

\section{Some complementary Government policies}

Because of the disproportionate cost of disruption or termination of schooling, in life chances for the student and in later social costs for the community, the Government has introduced policies to support schools and families, intended to supplement the legislative initiatives of the 1998 Act with regard to managing student behaviour. These policy decisions have created:
- District Truancy Services (DTSs), to provide back-up through community networks for schools' work on absenteeism and truancy (Budget provision of $\$ 2.5$ million in 1996/7 rising to $\$ 5$ million in 1997/8 and succeeding years, so that all schools now have access to the programme);

- School-based Alternative Education Provision providing 100 secondary places in 1997/8, rising to 250 and 400 in succeeding financial years, with schools invited to participate, often in partnership with a community organisation, and with the students funded at $\$ 5800$ per place for this "second chance education" over and above the standard resourcing for staffing and operations;

- Special Education 2000, in particular the Special Education Grantadded to the Operations Grant of all schools ( $\$ 55$ million per annum ongoing, and loaded towards lower decile schools) and the Severe Behaviour Difficulties Initiative which will give schools access to school-based Resource Teachers: Behaviour and Learning backed up by a Behaviour Specialist Support Service (with funding for a pilot scheme in 1998 and expansion New Zealand-wide from 1999);

- The Strengthening Families initiatives which seek to achieve greater co-ordination of personnel from health, education and social welfare departments and agencies as they work with families at risk, using wherever possible a "lead carer" from a "lead agency".

The proposal for an Education Review Tribunal was not taken up by the Government. It was seen as increasing the levels of bureaucracy that would be involved in resolution of issues of student behaviour. It was considered likely to cause delays, because the additional procedural step would be increasingly likely to be used, simply because it was available. The Government has therefore emphasised, in both the legislation and in the policies noted above, the need for school-based responses, with suitable back up, in matters of learning difficulties and the managing of student behaviour.

\section{Conclusion}

Contending paradigms of "an education market" and of "a network of schools" are currently in tension the one with the other concerning the equitable and/or efficient provision of access to education in New Zealand. They define in quite different ways the roles and responsibilities in education of the State, the schools, the students and 
their families, and the local community. The writer concurs with the late Commissioner for Children that the pattern of suspensions in New Zealand schools flows from the recent prominence of the market paradigm.

To use "traditional Kiwi-speak", the education network paradigm would lay on all parties that they take their "fair share" of responsibility for all students, including the disadvantaged, in the provision of a primary good essential to full participation in New Zealand society (Codd, 1993). In "post-1984 new Kiwi-speak" the market paradigm proposes that all players " seek out their competitive advantage" - lest the "disciplines of the market" overwhelm them. Concern for the disadvantaged will very likely prove at least in the short term counter-productive - equally to the schools advantaged in the market, and to those families better able to play the market.

A criterion for assessment of quality in the network model, derived from fitness for purpose, is clearly the extent to which the network can extend equality of educational opportunity, equitable fair shares. I find it difficult to derive a criterion for assessing the successful implementation of an education market model. Is it that only one secondary school fails in the market in any given year - as happened at Petone in 1998? It is no consolation that the answer to the analogous question about the quasi-market in New Zealand's health sector is proving just as difficult and costly (in several senses) to resolve.

The two paradigms will continue to be in tension within education administration as the changes of the Education Amendment (No. 2) Act 1998 are implemented, notwithstanding explicit reference to "the network of schools" within its new enrolment scheme provisions. In the wider New Zealand society policies emphasising decisions by the "logic" of the market continue to be promoted. They have created a significant constituency that feels it has benefited from the ensuing changes and "freedoms".

Without significant change in the wider social environment, the market paradigm is likely to continue to predominate. There are likely as a consequence to be continued adverse patterns in suspension statistics. If there are continued representations of unfair procedures persisting after the negotiation and publication of the new procedural rules, there will be, in response, demands for further change, at least by those being disadvantaged and by their advocates. It is equally probable that there will be resistance to change from those at present advantaged by the market.
Parties such as Community Law Projects and those involved in the field of Youth Justice are likely to press for greater recognition of human rights, spelt out in international conventions to which New Zealand is a party. Subsequent legislative change could yet see boards and principals lose their discretionary powers of "suspension" and "exclusion" (but probably not of "stand down") - and see the institution of an independent body or service, to hear or review issues relating to the right to attend New Zealand schools.

The UN Convention on the Rights of the Child in Article 10 provides for the child to be heard in any administrative procedure affecting the child. This right has been incorporated in the 1998 Act. Article 40 of the Convention, however, with regard to the impact on a child of the penal law, stresses the desirability of "promoting the child's reintegration and the child's assuming a constructive role in society". Article 3 is quite explicit that in any actions concerning children, whether undertaken by public or private social welfare institutions, courts of law, administrative or legislative bodies, the best interests of the child shall be the primary consideration [emphasis added].

These rights are already recognised in the procedures of the Youth Justice system and in Social Welfare legislation - they are not yet as explicit in Education law. Any future debate will be well served if it is accompanied by discussion at a deeper level on how concepts of "rights" and "reintegration", rather than concepts of "good order", "the greater good" and "the discipline climate" should underpin procedures for the appropriate retention of students in education.

On a matter of detail, further debate could consider whether the concept of "expulsion" is still appropriate (in the legislation it is applied only to students 16 and over), when the right to attend a school continues to age 19 , and 80 percent of students are in fact still at school on their seventeenth birthday.

Notes

1. An initial version of this paper, dealing with both suspensions and enrolment issues, was prepared for the Third International Conference of SAELPA (the South Africa Education Law and Policy Association) held in Pretoria, September 16-18, 1998, with the theme Developing a Rights Culture in Education. At the time of writing, in June, the Bill had been reported back from the Select Committee - but debate had then been suspended. 
2. The paper is written by a participant observer whose duties from 1991 to mid-1998 as Senior Policy Analyst within the Ministry of Education included the role of "shepherd of legislation". In no way, however, is it to be taken as a statement of the policy of the Minister of Education or of the Ministry of Education.

\section{References}

Ball, S., Bowe, R. \& Gewirtz S. (1995). Circuits of schooling: A sociological exploration of parental choice in social class contexts. Sociological Review, 43, 52-78.

Beeby, C. E. (1992). The Biography of an idea: Beeby on education. Wellington: New Zealand Council for Educational Research.

Codd, J. A. (1993). Equity and choice: The paradox of New Zealand education reform. Curriculum Studies, (1)1, 75-90.

Grace, G. (1995). School leadership: Beyond education management: An essay in policy scholarship. London: Falmer Press.

Lauder, H., Hughes, D., Waslander, S., Thrupp, M., McGlinn, J., Newton, S., \& Dupuis, A. (1994). The creation of market competition in education in New Zealand. Wellington: Victoria University of Wellington.

Minister of Education. (1997-8). New Zealand schools: Nga Kura o Aotearoa 1996 and 1997: Reports on the compulsory school sector in New Zealand. Wellington: Learning Media.

O'Reilly, L. (1997). Education Review Tribunal: Briefing paper for the Minister of Education on the need for an Education Review Tribunal. Wellington: Office of the Commissioner for Children (mimeo).

Overton, A. (1995). Circumstances leading to the suspension of students from Christchurch secondary schools. Christchurch:Education Department, University of Canterbury (mimeo).

Rae, K. (1998, September). The right to attend school in New Zealand: School choice, enrolments and suspensions and potential impacts of the 1997 Education Legislation Amendment Bill. Paper presented to the South Africa Education Law and Policy Association (SAELPA) Conference, Pretoria.

Thrupp, M. (1995). Poor performers or just plain poor? Assumptions in the neo-liberal account of school failure. Waikato Journal of Education, 1, 45-60.

Thrupp, M. (1997). How school mix shapes school processes: A comparative study of New Zealand schools. New Zealand Journal of Educational Studies, (32)1, 53-82.
Wylie, C. (1997). Self-managing schools seven years on: What have we learned? Wellington: New Zealand Council for Educational Research.

\section{The author}

Ken Rae retired in August 1998 after nine years as Senior Policy Analyst in the Education Management Policy section of the Ministry of Education. The section had responsibility for policy development and advice to Government on the resourcing and management of education at macro and micro levels across the school and early childhood sectors. It had responsibility with the Legal section for support for the Minister for legislation proposals through to approval at Cabinet level and then through all the stages in the House.

Prior to the restructuring of education administration in 1989 he had served as a Senior Education Officer in both Northern and Central Regional Offices of the former Department of Education, and more briefly on two occasions in the Schools Directorate in the Head Office. As a secondary teacher he had earlier held positions in schools in the Auckland region.

Contact: Ken Rae, 4a Paua Place, Plimmerton, Porirua City, New Zealand. 